\title{
VALIDATION OF A TRAINING PROTOCOL FOR MARCHA CONTESTS OF THE MANGALARGA MARCHADOR BREED
}

\author{
VALIDAÇÃO DE UM PROTOCOLO DE TREINAMENTO PARA PROVAS DE \\ MARCHA DA RAÇA MANGALARGA MARCHADOR
}

\section{Renata Guimarães Pequeno ABRANTES; Adalgiza Souza Carneiro de REZENDE; Juliano Martins SANTIAGO; Pablo TRIGO; Marília Martins MELO; Mayara Gonçalves FONSECA; Jéssica LAGE; Dalton Colares de Araújo MOREIRA}

1. Médica Veterinária, Mestranda do Programa de Pós-graduação em Zootecnia da Escola de Veterinária - EV, Universidade Federal de Minas Gerais - UFMG, Campus Pampulha, Belo Horizonte, MG, Brasil; 2. Médica Veterinária, Dsc., Professora Associada do

Departamento de Zootecnia EV - UFMG; Belo Horizonte, MG, Brasil. adalgizavetufmg@ gmail.com; 3. Médico Veterinário, Dsc.,

Professor Adjunto da Universidade Federal Rural de Pernambuco, Serra Talhada, PE, Brasil; 4. Médico Veterinário, Dsc., Pósdoutorando da Universidade Federal Rural do Rio de Janeiro, Seropédica, RJ, Brasil; 5. Médica Veterinária, Dsc., Professora Associada do Departamento de Clínica e Cirurgia Veterinárias, EV - UFMG, Belo Horizonte, MG, Brasil; 6. Médica Veterinária, Mestranda do Programa de Pós-graduação em Zootecnia da Escola de Veterinária - EV, UFMG, Belo Horizonte, MG, Brasil; 7. Discente do curso de Medicina Veterinária da EV - UFMG, Belo Horizonte, MG, Brasil; 8. Médico Veterinário, graduado pela EV - UFMG, Belo Horizonte, MG, Brasil.

\begin{abstract}
The Mangalarga Marchador breed is functionally evaluated through marcha contests. The present research aimed to verify the efficacy of a training protocol for conditioning Mangalarga Marchador horses for marcha contests. Eight mares were used in a completely randomized block split-plot design, where each animal was a block, the physical tests (T I, T II, T III, T IV and T V) every 21 days of training were the plots, and the time of evaluation and collection of samples inside each test were the split-plots. The mares were trained for 84 days for one hour a day, five days a week, with rest on Saturdays and Sundays. On Mondays, Wednesdays, and Fridays, the animals warmed up in an oval track by walking for 10 minutes and then marching for a period established individually through a marcha test. Next, the animals were led in walk gait until an hour of exercise was completed. On Tuesdays and Thursdays, the animals were trained outdoors for one hour only walking. The tests consisted of successive 10 minutes stages at marcha, which was interrupted when heart rate reached 150 beats per minute and lactate levels were greater than $4 \mathrm{mmol} / \mathrm{L}$, or after $70 \mathrm{~min}$ of the test. Marcha duration, heart rate and blood concentrations of lactate were evaluated. The results were submitted to an analysis of variance and the averages were compared by Fisher's test at 5\% probability. From zero at nine weeks of training, marcha duration increased progressively $(\mathrm{p}<0.05)$, but there was no difference $(\mathrm{p}>0.05)$ between nine and 12 weeks of training. The training protocol used was appropriate to condition Mangalarga Marchador equines to compete in marcha contests following the rules of Brazilian Association of Mangalarga Marchador Breeders.
\end{abstract}

KEYWORDS: Conditioning. Equus caballus. Heart rate. Lactate.

\section{INTRODUCTION}

The athlete horse must undergo a training regimen aiming at preparing it to the contests. This training must have regular exercise and rest periods so as to promote structural and physiological changes in the organism in order to improve performance in the competitions, besides decreasing the risk of injuries (HODGSON; ROSE, 1994). The main adaptations take place in the cardiovascular system, in the muscle cells, and in structural elements such as bones and tendons. To Evans (2008), an efficient response to training depends on the stimulus caused and each animal must be trained according to its temper and exercising ability.

As horse breeding advances in the country and equestrian sports become popular, the Mangalarga Marchador breed has been increasingly subjected to adverse situations such as heavy exercise, long-distance travel, and all sorts of competition-related stress. Nevertheless, there are no studies aiming to evaluate the training period and protocol to be adopted for this important Brazilian breed which, besides having marcha as a gait, is bred in a country with different climate and terrain compared to the origin of most researches in equine breeding. That leads breeders to train their animals based on experience or in scientific outcomes from researches carried out with breeds that do not compete in marcha contests.

The marcha contest is this breed's main competition, in which the Mangalarga Marchador equines are functionally assessed. In these contests, the animal marches uninterruptedly for a long time around a circular course at speeds of 9 to $12 \mathrm{~km} / \mathrm{h}$ (PRATES et al., 2009). The General Rules for the breed's events establish that the judging in each 
contest must last at most 70 minutes and at least 20 minutes (ABCCMM, 2009).

According to Jackman (2004), the horses very often join competitions before being fully prepared, which causes stress to muscles, bones, ligaments, and tendons and leads to injuries. Claudication is the main cause of reduced performance and may limit or even end the animals' athletic activity (JACKMAN, 2004).

The lack of information on the training to be recommended to Mangalarga Marchador animals aiming to take part in marcha contests has motivated the current study to be conducted, with the goal of verifying the efficacy of a training protocol for marching equines to reach appropriate physical conditioning for competitions.

\section{MATERIAL AND METHODS}

The procedures used in this experiment were approved by the Ethics Committee for Animal Experimentation of the Federal University of Minas Gerais (CETEA/UFMG), filed under protocol 255/11.

The experimental phase was developed at Haras Catuni, in the municipality of Montes Claros/MG. Eight Mangalarga Marchador females between three and five years old and weighing 353 $\pm 21.19 \mathrm{~kg}$ were used. Before beginning the experiment, the mares had never undergone any training and were raised free in a pasture with water and mineral salt ad libitum. On week prior to the experiment, all mares were given anthelmintic medication and washed with an anti-tick solution.

The experiment used a completely randomized block split-plot design. The animals (eight mares) represented the blocks; the plots were the training times zero week (test I), three weeks (test II), six weeks (test III), nine weeks (test IV) and 12 weeks (test V), and the split-plots were the moments of evaluation and blood collection before (baseline), during and after the marcha tests.

During the experimental phase, the animals remained in an 8.3 ha pen planted with Tanzania grass (Panicum maximum cv. Tanzania) with water and mineral salt (Coequi Plus - Tortuga) ad libitum. The concentrate feed (Rações Total Alimentos) was offered at 8 A.M. and at 5 P.M. in service areas built according to Carvalho e Haddad (1987).

The mares were trained for 84 days for one hour a day, five days a week, with rest on Saturdays and Sundays. On Mondays, Wednesdays, and
Fridays, the animals warmed up in an oval track by walking for ten minutes and then marching for a period established individually through a marcha test. Next, the animals were led in walk gait until an hour of exercise was completed. A limit of 40 minutes was set for the marcha during training. On Tuesdays and Thursdays, the animals were trained outdoors for one hour only walking on different terrains and surfaces.

The first marcha test (T I) was carried out one day prior to the training period and every 21 days after that in order to define the time each animal would march for the next 21 days of training. The marcha test protocol consisted of five minutes warming up walking $(4-5 \mathrm{~km} / \mathrm{h})$ followed by ten minutes marching at constant GPS-controlled speed of $12-13 \mathrm{~km} / \mathrm{h}$. By the end of each series, blood lactate levels and heart rate were monitored using a hand-held lactate meter (Accutrend Plus - Roche) and a heart rate monitor (Polar - Equine). The tests were interrupted when the animals had blood lactate levels $\geq 4 \mathrm{mmol} / \mathrm{L}$ and heart rate $\geq 150$ beats per minute (bpm).

The individual physical assessment data marcha duration (series number of the tests completed by animals until had blood lactate levels $\geq 4 \mathrm{mmol} / \mathrm{L}$ and heart rate $\geq 150 \mathrm{bpm}$ ), heart rate and blood concentration of lactate were written down in spreadsheets for each of the five tests. The heart rate was also measured during the recuperation after the tests. Indexes speeds needed to reach blood lactate concentrations of $2\left(\mathrm{La}_{2.0}\right)$ and 4 $\mathrm{mmol} / \mathrm{L}\left(\mathrm{La}_{4.0}\right)$ were estimated by exponential regression use of the software SAEG (version 9.1). The results marcha duration, heart rate, $\mathrm{La}_{2.0}$ and $\mathrm{La}_{4.0}$ were submitted to an analysis of variance and the averages were compared by Fisher's test at 5\% probability with the use of the software SAEG (version 9.1).

\section{RESULTS AND DISCUSSION}

Table 1 shows the increase $(p<0.05)$ in marcha duration from zero week (T I) to nine weeks of training (T IV), pointing out the animals' gain in physical conditioning from the training. However, no difference $(\mathrm{p}>0.05)$ was found in the marcha duration the animals could bear between test IV an 12 weeks of training ( $\mathrm{T} \mathrm{V}$ ). Both the gain of physical conditioning up to test IV and the its maintenance in test $\mathrm{V}$ can be seen in the heart rate and blood lactate levels. 
Table 1. Comparison of the marcha duration (minutes) the animals could bear in each of the tests during the experimental period.

\begin{tabular}{lllllll}
\hline Test & I & II & III & IV & V & CV (\%) \\
\hline $\begin{array}{l}\text { Marcha } \\
\begin{array}{l}\text { duration } \\
\text { (min) }\end{array}\end{array}$ & $12.50^{\mathrm{c}}$ & $15.00^{\mathrm{c}}$ & $47.50^{\mathrm{b}}$ & $68.75^{\mathrm{a}}$ & $55.00^{\mathrm{ab}}$ & 35.1 \\
\hline $\begin{array}{l}\text { Different letters differ between the tests according to Fisher's test }(\mathrm{p}<0.05) \\
\text { r }\end{array}$ &
\end{tabular}

Table 2 shows the marcha time needed for the animals to reach $2 \mathrm{mmol} / \mathrm{L}\left(\mathrm{La}_{2.0}\right)$ and 4.0 $\mathrm{mmol} / \mathrm{L}\left(\mathrm{La}_{4.0}\right)$ in each test. It can be seen that training made the animals take longer to reach $\mathrm{La}_{2.0}$ and $\mathrm{La}_{4.0}$, which shows how important the evaluation of this metabolic variable is to estimate the level of conditioning of Mangalarga Marchador equines in training for marcha competitions so as to estimate the increase in training time each animal must undergo at each phase of training.

Table 2. Marcha time (minutes) needed for the blood lactate level to reach $2.0 \mathrm{mmol} / \mathrm{L}\left(\mathrm{La}_{2.0}\right)$ and $4.0 \mathrm{mmol} / \mathrm{L}$ $\left(\mathrm{La}_{4.0}\right)$ in the five tests carried out during training.

\begin{tabular}{ccccccc}
\hline Test & I & II & III & IV & V & CV \% \\
\hline $\mathrm{La}_{2.0}$ & $1.14^{\mathrm{b}}$ & $1.37^{\mathrm{b}}$ & $6.58^{\mathrm{a}}$ & $8.65^{\mathrm{a}}$ & $8.62^{\mathrm{a}}$ & 33.4 \\
$\mathrm{La}_{4.0}$ & $8.08^{\mathrm{b}}$ & $9.93^{\mathrm{b}}$ & $42.66^{\mathrm{a}}$ & $58.79^{\mathrm{a}}$ & $45.87^{\mathrm{a}}$ & 12.3 \\
\hline
\end{tabular}

Different letters differ between the tests according to Fisher's test $(\mathrm{p}<0.05)$

Table 2 also shows that, by nine weeks of training (T IV), these animals were already able to compete in a marcha contest with no risk of injuries due to excess lactate and consequent reduction in muscle $\mathrm{pH}$. Over the experimental period (84 days), the horses did exercises below the lactate threshold (4 mmol/L), which led to a predominantly aerobic effort. This is recommended for animals that have never been trained aiming at improving their osteotendon resistance (RIVERO, 2007).

According to Ferraz et al. (2010), the main purpose of this type of effort, also called resistance phase or base training, is improving aerobic ability and resistance of the musculoskeletal system, thus lowering the frequency of locomotor system illnesses (D'ANGELIS et al., 2005). According to Ferraz et al. (2008), assessing athletic performance by determining lactate is crucial in training program for animals that need to improve aerobic ability. The results obtained in the current study are in accordance with Ferraz et al. (2008) and Ferraz et al. (2010). It can be seen that the lactate dynamics in the organism can be improved since aerobic training reduced hyperlactatemia after exercise.

Table 3 shows the heart rate values before, during and after the tests. It can be seen that there was no reduction in heart rate between zero week ( $T$ I) and nine weeks of training (T IV), which justifies the increase in marcha duration as a consequence of training.

Table 3. Heart rate (beats per minute) obtained by the animals before, immediately after, and at 30 and 60 minutes after the marcha tests carried out during the experimental period.

\begin{tabular}{cccccc}
\hline Test & Before & $\begin{array}{c}\text { Immediately } \\
\text { after }\end{array}$ & $30^{\prime}$ & $60^{\prime}$ & $\mathrm{CV}(\%)$ \\
\hline I & $53.33^{\mathrm{Ab}}$ & $163.00^{\mathrm{Aa}}$ & $57.66^{\mathrm{Ab}}$ & $53.50^{\mathrm{Ab}}$ & \\
II & $51.75^{\mathrm{Ab}}$ & $160.75^{\mathrm{ABa}}$ & $59.00^{\mathrm{Ab}}$ & $52.87^{\mathrm{Ab}}$ & \\
III & $52.36^{\mathrm{Ab}}$ & $141.75^{\mathrm{CDa}}$ & $61.75^{\mathrm{Ab}}$ & $56.5^{\mathrm{Ab}}$ & 14,0 \\
IV & $45.25^{\mathrm{Ac}}$ & $136.37^{\mathrm{Da}}$ & $62.62^{\mathrm{Ab}}$ & $57.71^{\mathrm{Ab}}$ & \\
V & $42.87^{\mathrm{Ab}}$ & $149.87^{\mathrm{BCa}}$ & $56.00^{\mathrm{Ab}}$ & $52.00^{\mathrm{Ab}}$ & \\
\hline
\end{tabular}

Different capital letters show differences among the tests according to Fisher's test $(\mathrm{p}<0.05)$; Different small letters differ among the collection times according to Fisher's test $(\mathrm{p}<0.05)$

Test $\mathrm{V}$ shows higher heart rate than the previous test, which justifies the reduction in marcha duration in test $\mathrm{V}$ compared to test IV.
Throughout the experimental period, no lameness or changes in behavior were seen that would justify a reduction in animal performance. 
Table 1 also shows that in test IV, or at 63 days of training, the animals were already conditioned for a marcha contest of approximately 70 min as mandated by the ABCCMM (2009) rules. Rivero e Piercy (2008) reported that the most relevant adaptations deriving from training take place in the first three to four months. By extending this time, despite the improvement in aerobic ability, there is a higher risk of overreaching. This risk may present in marching animals earlier than in trotting animals since the marcha seems to demand more wear and energy expenditure from the animals because during its dynamics the animals never lose contact with the ground (PROCÓPIO, 2005).

Pösö et al. (2004) claimed that, when no apparent cause seems to be the reason for a reduction in performance, the training program should be evaluated. Short-term overreaching occurs due to poor adaptation to the program with a consequent reduction in appetite, irritability, and reluctance to exercise. To those authors, two weeks of rest are enough for an improvement. This condition occurs when the training volume is too great or the interval between exercises is too short.

Another hypothesis for the lack of gain in conditioning after 63 days of training is the lack of enough stimulus during this period. Hinchcliff e
Geor (2008) reported that, in order to have the desired effect, light training should be a repetition of stimuli. If the work, on the other hand, is carried out with not enough time for total recovery, the overall exercises carried out may be insufficient to reach conditioning when compared to programs that allow for better recovery. According to those authors, the art of training horses involves the careful use of exercises at different intensities and durations so as to lead to optimal adaptations that will enable competing successfully while preventing injuries and overreaching.

\section{CONCLUSION}

The training protocol used was appropriate to condition Mangalarga Marchador equines to compete in marcha contests following the rules of ABCCMM.

\section{ACKNOWLEDGEMENTS}

Haras Catuni, Fundação de Amparo à Pesquisa do Estado de Minas Gerais (FAPEMIG), Conselho Nacional de Pesquisa (CNPq) and Total Alimentos.

RESUMO: A raça Mangalarga Marchador é avaliada funcionalmente através das provas de marcha. O presente estudo objetivou verificar a eficácia de um protocolo de treinamento para condicionar equinos Mangalarga Marchador visando participação em provas de marcha. Foram utilizadas oito éguas em delineamento de blocos ao acaso com esquema de parcelas subdivididas, onde cada animal constituiu um bloco, as parcelas foram representadas pelos testes físicos ( $\mathrm{T}$ I, $\mathrm{T}$ II, T III, T IV e T V) realizados a cada 21 dias do treinamento e as subparcelas foram constituídas pelos tempos de avaliação e coletas de amostras em cada teste. As éguas foram treinadas durante 84 dias, uma hora por dia, cinco dias por semana, com descanso aos sábados e domingos. Nas segundas, quartas e sextas-feiras, os animais realizavam 10 minutos de aquecimento ao passo em uma pista oval, em seguida marchavam por um tempo individual de marcha, estabelecido em um teste prévio. Depois, caminhavam até completar uma hora de exercício. Na terças e quintas-feiras eram montadas ao passo por uma hora. Os testes foram formados por etapas sucessivas de 10 minutos de marcha, sendo interrompido quando a frequência cardíaca atingia 150 batimentos por minuto e a concentração de lactato era maior que $4 \mathrm{mmol} / \mathrm{L}$ ou a prova atingisse 70 minutos de duração. Avaliou-se o tempo de marcha, frequência cardíaca e concentração sanguínea de lactato. Os resultados foram submetidos à análise de variância e as médias comparadas pelo teste de Fisher a 5\% de probabilidade. De zero a nove semanas de treinamento, o tempo de marcha aumentou progressivamente $(\mathrm{p}<0,05)$, mas não houve diferença $(p>0,05)$ entre nove e doze semanas de treinamento. O protocolo de treinamento adotado foi adequado para condicionar equinos Mangalarga Marchador para competir em uma prova de marcha realizada de acordo com a regulamentação da Associação Brasileira de Criadores do Cavalo Mangalarga Marchador.

PALAVRAS-CHAVE: Condicionamento. Equus caballus. Frequência cardíaca. Lactato

\section{REFERENCES}

ASSOCIAÇÃO BRASILEIRA DOS CRIADORES DO CAVALO MANGALARGA MARCHADOR. ABCCMM. Regulamento Geral para Eventos Oficializados do Cavalo Mangalarga Marchador. Belo Horizonte: ABCCMM, 2009. 54 p. 
CARVALHO, R. T. L.; HADDAD, C. M. Pastagens e alimentação de equinos. Piracicaba: FEALQ, 1987. 85 p.

D’ANGELIS, F. H. F.; FERRAZ, G. C.; BOLELI, I. C.; LACERDA-NETO, J. C.; QUEIROZ-NETO, A. Aerobic training, but not creatine supplementation, alters the gluteus medius muscle. Journal of Animal Science, Champaign, v. 85, p. 579-585, 2005.

EVANS, D. Exercise testing in the field. In: HINCHCLIFF K. W.; GEOR R. J.; KANEPS A. J. (Ed.). Equine Exercise Physiology: The Science of Exercise in the Athletic Horse. Philadelphia: Elsevier, 2008. p. 13-27. http://dx.doi.org/10.1016/B978-070202857-1.50004-4

FERRAZ, G. C.; D’ANGELIS, F. H. F.; TEIXEIRA-NETO, A. R.; FREITAS, E. V. V.; LACERDA-NETO, J. C.; QUEIROZ-NETO, A. Blood lactate threshold reflects glucose responses in horses submitted to incremental exercise test. Arquivo Brasileiro Medicina Veterinária e Zootecnia, Belo Horizonte, v. 60, n. 1, p. 256-259, 2008. http://dx.doi.org/10.1590/S0102-09352008000100035

FERRAZ, G. C.; TEIXEIRA-NETO, A. R.; PEREIRA, M. C.; LINARDI, R. L.; LACERDA-NETO, J. C.; QUEIROZ-NETO, A. Influência do treinamento aeróbio sobre o cortisol e glicose plasmáticos em equinos. Arquivo Brasileiro de Medicina Veterinária e Zootecnia, Belo Horizonte, v. 62, n. 1, p. 23-29, 2010. http://dx.doi.org/10.1590/S0102-09352010000100003

HINCHCLIFF, K. W.; GEOR, R. The Horse as an athlete: a physiological overview. In: HINCHCLIFF, K. W.; GEOR R. J.; KANEPS A. J. (Ed.). Equine Exercise Physiology: The Science of Exercise in the Athletic horse. Philadelphia: Elsevier, 2008. p. 2-11. http://dx.doi.org/10.1016/B978-070202857-1.50003-2

HODGSON, D. R.; ROSE, R. J. The athletic horse: principles and practice of equine sports medicine. Philadelphia: W.B. Saunders, 1994. 497 p.

JACKMAN, B. R. Veterinary aspects of training western performance horses. In: HINCHCLIFF, K. W; KANEPS, A. J.; GEOR, R. J. Equine sports medicine and surgery. Saint Louis: Saunders, 2004. p. 1123-1130. http://dx.doi.org/10.1016/B978-0-7020-2671-3.50057-X

PÖSÖ, A. R.; HYYPPÄ, S.; GEOR, R. J. Metabolic responses to exercise and training. In: HINCHCLIFF, K. W.; KANEPS, A. J.; GEOR, R. J. (Ed.). Equine Sports Medicine and Surgery. Philadelphia: Saunders, 2004. p. 771-792. http://dx.doi.org/10.1016/B978-0-7020-2671-3.50038-6

PRATES, R. C., REZENDE, H. C., LANA, A. M. Q. et al. Heart rate of Mangalarga Marchador mares under march test and supplemented with chrome. Revista Brasileira de Zootecnia, v. 38, n. 5, p. 916-922, 2009.

PROCÓPIO, A. M. Análise cinemática da locomoção de equinos marchadores. 2005. 69 f. Tese (Doutorado em Zootecnia) - Escola de Veterinária, Universidade Federal de Minas Gerais, Belo Horizonte, 2005. http://dx.doi.org/10.1590/S1516-35982009000500019

RIVERO, J. L. A scientific background for skeletal muscle conditioning in equine practice. Journal of veterinary medicine. A, Physiology, pathology, clinical medicine, Berlin, v. 6, n. 54, p. 321-332, 2007.

RIVERO, J. L.; PIERCY, R. J. Miscle physiology: responses to exercise and training. In: HINCHCLIFF, K. W.; GEOR, R. J.; KANEPS, A. J. (Ed.). Equine Exercise Physiology - The Science of Exercise in the Athletic horse. Philadelphia: Elsevier, 2008. p. 30-80. 